Available online at: $\mathrm{http}: / /$ journals.rsfpress.com/index.php/ijmesh

International Journal of Management, Entrepreneurship, Social Science and Humanities (IJMESH)

ISSN 2580-0981 (online)

Volume 3 Number 1 (2020): 1-15

\title{
The Influence of Determining Factors on Islamic Stock Index in Indonesia
}

Azhar Alam1, Galuh Thifal Anggraeni' ${ }^{2}$, Muhammad Anas ${ }^{3}$

1 Universitas Muhammadiyah Surakarta, Indonesia

\begin{abstract}
This paper investigated some determining factors that influence Indonesia Sharia Stock Index (ISSI). Some macroeconomic variables are used as an independent variable such as central bank interest rates, inflation, currency exchange rate, and return rates of Bank Indonesia Sharia Certificates (SBIS). This study conducted the Error Correction Model (ECM) to analyze times series data during October 2013 and September 2017. The findings showed that Indonesia Sharia Stock Index (ISSI) is influenced significantly and negatively by central bank interest rates in long term analysis. Similarly, in short term analysis, the central bank interest rates affect significantly and negatively on ISSI as well as the currency exchange rates. On the other hand, SBIS return rates and inflation are indicated to have a non-significant negative effect on ISSI. This study suggested that investors of ISSI consider Central Bank interest rates, inflation, rupiah exchange rates, and SBIS rates of return to predict the stock price so investors can make the right decisions in their investment policies. This paper also recommended the Indonesian Central Bank to effectively manage their monetary policy and promote ISSI as an alternative investment which is resistant by the negative effect of inflation in short term analysis.
\end{abstract}

Keywords:Islamic Stock Index; Central Bank Interest Rates; Currency Exchange Rates; Inflation; Bank Indonesia Sharia Certificates

This is an open access article under the CC-BY-NC license.

\section{INTRODUCTION}

The capital market is a financial institution that has a vital role in managing state and community investment. The amount of investor contribution in a country is marked by the level of fund mobility in the capital market. The mobility of funds shows the high intensity of companies that use the capital market as a source of funds. Companies that get the injection of funds through the sale of shares, bonds, and other forms of securities will get fresh funds to meet the input of production.

The fulfillment of production inputs will increase production targets in the market so that companies can optimize profits from the output of production. If the company's income rises, it will undoubtedly encourage an increase in people's income, which in turn will affect the increase in consumption of goods and services, which in the end, in the aggregate economy an increase in capital mobility in the capital market will increase the welfare of the community. Therefore, the capital market can be justified as a generator for the national economy (Rachmawati \& Laila, 2015).

Islamic capital market has attracted worldwide attention since it generated fund sources from Muslim and non-Muslim countries (Bahloul et al., 2017). Indonesia is a country with the largest Muslim population and has rapid growth in its Islamic capital market. One of the developments in the mobility of funds in the capital market can be seen from the performance of the Indonesian Syariah Stock Index (ISSI). Sharia Stock Index (ISSI) issued by Bapepam- LK and the National Sharia Council of the Indonesian Ulema Council (DSN-MUI) on May 12, 2011.

ISSI is a Sharia Stock Index consisting of all shares listed on the Indonesia Stock Exchange (IDX) and joins the Syariah Securities List (DES). The Indonesia Shariah Stock Index was created to provide answers to the public who want to know the performance of all sharia shares so that it will make it easier for capital market players to measure the performance of sharia shares. Although it was formed in May 2011, the development of the Indonesia Sharia Stock Index (ISSI) in each period is quite significant Corresponding author aa123@ums.ac.id; galuhthifal@gmail.com; ma912@ums.ac.id DOI: https://doi.org/10.31098/ijmesh.v3i1.120 
(Aisiyah \& Khoiroh, 2015). At the end of 2015, the Islamic stock market share growth was more dominant compared to the conventional stock market. In terms of products, the number of sharia shares reached 318 shares or $61 \%$ of the total market capitalization of the Indonesian stock market (Terhadap \& Saham, 2018).

The development of the Indonesia Sharia Stock Index (ISSI) during the period of October 2013 September 2017 can be seen in Figure 1

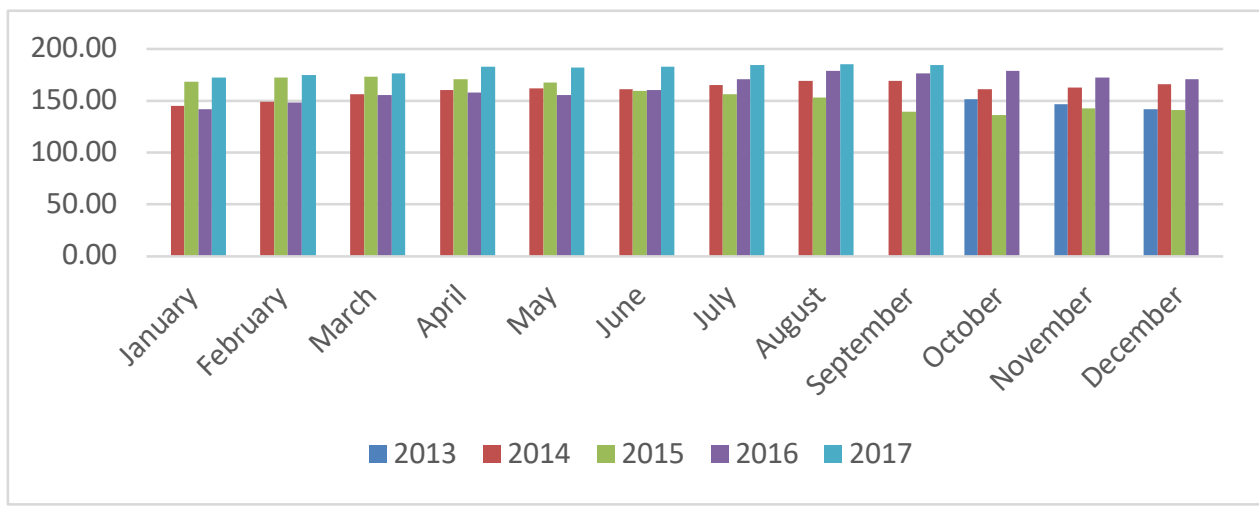

Fig. 1 ISSI Development period October 2013 - September 2017 (points)

Source: https://www.duniainvestasi.com/bei/prices/stock/ISSI, accessed at 14 Oktober 2018

time $\underline{21.31}$

Based on Figure 1, it can be seen the development of the Indonesian Sharia Stock Index (ISSI) from October 2013 to September 2017, which experienced fluctuations. In October 2013, the Indonesia Sharia Stock Index (ISSI) was 151.2775 points. Then it went up and down in the next period and began to see a significant increase in July 2016 that was 170.5211 points and was still up and down until the end of 2016. Indonesia Sharia Stock Index was seen the highest in August 2017 amounting to 185.4932 points while the lowest occurred in October 2015 by 136,0250 points.

Despite growing investment in the Islamic capital market, unfortunately, there is the fact that the low market share of the global Islamic capital market indicated the emerging phase in Indonesia (Setiawan \& Kanila Wati, 2019). One of the reasons is financial literacy in sharia equity funds still be a problem by only $0,02 \%$ (Otoritas Jasa Keuangan, 2017). This obstacle would slow the development of the capital market compared to countries where the people are more familiar with the world of capital markets (Saham et al., 2016).

Looking at the development of the Indonesia Sharia Stock Index (ISSI) and the minimum literacy among Islamic capital market investor, this study aims to measure and explain the influence of macroeconomic variables such as BI interest rates, inflation, the currency exchange rate and Bank Indonesia Sharia Certificates (SBIS) return rate on the Stock Index Syariah Indonesia (ISSI) during the period October 2013 to September 2017. This paper tries to help investors to determine the best steps in making investment decisions in the Islamic capital market.

\section{LITERATURE REVIEW}

Definition of Indonesia Sharia Stock Index

Halim (2005) defined that the stock price index is a summary of the simultaneous and complex influences of various influential variables, especially regarding economic events. The stock price index is 
also justified as the primary indicator that describes the movement of stock prices, so the composite of a stock price index (IHSG) illustrates a country's capital market outlook (Darmaji \& Hendi, 2006). According to Iskandar (2003) index in the capital market has a function to be an indicator of stock investment performance.

Indonesia Sharia Stock Index is a stock index reflecting the entirety of Islamic stocks listed on the Indonesia Stock Exchange (IDX). ISSI constituents are registered in the Sharia Securities List (DES). This is a collection of Securities which is not in conflict with the Sharia principles in the Capital Market and determined by Bapepam-LK or parties approved by Bapepam-LK. The ISSI constituents are reviewed every six months in May and November, which is published at the beginning of the following month. Constituents ISSI also adjusted if there are new Islamic stocks recorded or eliminated from Sharia Securities List (DES).

\section{Macroeconomic Effect on Stock Prices}

Kewal (2012) stated that interest rate fluctuations, inflation, the currency exchange rate, and GDP growth often become macroeconomic indicators that associate with the capital market. Good macroeconomic conditions that would attract investors to invest, it will affect the stock price and will undoubtedly make better economic growth.

Changes in macroeconomic factors such as specific government policies, money circulation, and economic condition will not immediately affect the company's performance, but slowly in the long run. Conversely, stock prices will be affected immediately by changes in macroeconomic factors because investors react faster. When changes in macroeconomic factors occur, investors will calculate their impact, both positive and negative, on the company's performance in the next few years, then decide to buy or sell the relevant shares. Therefore, stock prices adjust more quickly than company performance due to changes in macroeconomic variables (Samsul, n.d.). Good macroeconomic developments will affect company profits; this is caused by the emergence of investor confidence to invest. Higher growth rates and stable inflation will at least make company profits increase, and vice versa if economic growth is terrible it will reduce corporate profits and ultimately will reduce the share price (Samsul, n.d.). Natarsyah (2000) argued that a government that has reasonable economic growth goals tends to control inflation, keep the exchange rate stable and relatively low-interest rates.

Brigham and Houston (2013) stated that fundamental macroeconomic factors: inflation, interest rates, exchange rates, and economic growth are factors that are highly considered by the stock market players. Changes that occur in this factor can result in changes in the capital market, namely the increase or decrease in stock prices. The volatility of stock prices in the capital market can have the potential to increase or decrease systematic risk. Therefore, changes in macroeconomic factors can potentially increase or decrease systematic risk.

Systematic risk in stock price volatility is related to stock returns. Fabozzi (2000) stated that shares generally have two sources of risk that affect stock returns, namely systematic risk, and companyspecific risk or unsystematic risk. Risk is the risk that comes from economic conditions and general market conditions that cannot be defined. From this approach, the expected stock return formula is formed as a result of the sum of systematic risks and company-specific risks.

Effect of Central Bank Interest Rates on Stock Index

Sukirno (2014) argued that interest rates expressed as a percentage of capital. Interest rates describe the level of return on investment and describe the size of capital costs that must be incurred. 
Changes in interest rates can affect the variability of an investment's return. Changes in interest rates will affect stock prices in reverse using ceteris paribus assumption. That is, if interest rates increase, the stock price will go down and vice versa. This condition potentially attracts the interest of investors who previously invested in shares to move funds from stocks into deposits. If most investors take the same action, many investors will sell shares to invest in deposits. Under the supply-demand law, if many parties sell shares, at ceteris paribus condition, then the share price will go down (Tandelilin, 2010).

An increase in the loan interest rate harms each issuer because it will increase the interest expense on loans and reduce net income. The decline in net income will result in earnings per share also decline and will eventually result in a decline in stock prices in the market. On the other hand, rising deposit rates will encourage investors to sell shares and then save the proceeds of the sale in deposits. The sale of shares on a large scale will bring down stock prices on the market. Therefore an increase in loan interest rates or deposit rates will result in a decrease in stock prices (Samsul, n.d.).

\section{Effect of Inflation on Stock Index}

Inflation is the state of the economy, characterized by a rapid increase in the product price and has an impact on declining purchasing power. This often also followed by a decrease in the level of savings and investment due to increased public consumption and only a little for long-term savings. Inflation also can be defined as a process of rising prices that prevails in an economy (Karya \& Syamsudiin, 2016; Sadono Sukirno, 2013).

Uncertainty about the purchasing power of income is to be received in the future as a return on investment. In everyday language, this risk is known as the impact of inflation and deflation of an investment. Inflation is a condition of an increase in the general price level in an economy that causes a decrease in purchasing power and demand that is fixed. Deflation is the opposite condition of inflation, namely a decrease in the general price level (Manurung \& Manurung, 2009). There are two essential factors as causes of inflation, and both come from demand and supply sides.

The inflation rate can have positive or negative effects depending on the degree of inflation itself. Excessive inflation can hurt the economy as a whole, which can make many companies go bankrupt. So, it can be concluded that high inflation will bring down stock prices in the market. While slow and meager inflation will result in slow economic growth, and ultimately stock prices are also slow (Samsul, n.d.).

\section{Effect of Currency Exchange Rates on Stock Index}

Karya and Syamsudin (2016) defined the exchange rate is the large amount of domestic money needed to obtain a unit of foreign currency. Rupiah exchange rates with foreign exchange rates will affect the issuer's stock prices. This can be explained as follows: the rupiah exchange rate will affect company sales (especially for export-oriented business issuers), cost of sold goods (affect raw material purchases if obtained from imports), and exchange rate losses. Specifically for foreign exchange losses, especially for companies that have obligations in foreign currencies, will be significantly affected by the depreciation and appreciation of the rupiah.

The decline in the exchange rate of the rupiah against foreign currencies (US dollars) has an impact on the rising costs of imports of raw materials and equipment needed by the company so that it results in increased production costs, or in other words, the weakening of the rupiah against the US dollar hurts the national economy finally reduce the performance of shares in the stock market The control of the rupiah exchange rate or commonly referred to as intervention on the rupiah exchange rate 
is carried out by Bank Indonesia as a monetary policy measure in achieving the economic goals set by the government.

A sharp rise in the US \$ exchange rate against the rupiah will negatively impact issuers that have debt in dollars while the issuer's products are sold locally. Meanwhile, export-oriented issuers will receive a positive impact from the increase in the US \$ exchange rate. This means that issuers affected negatively will experience a decline on the Stock Exchange, while issuers affected positively will increase their share prices (Samsul, n.d.)

The effect of the exchange rate will be different for export-oriented companies. Companies will benefit from the depreciation of the rupiah because foreign income will be more significant if exchanged for rupiah. If there is an increase in the exchange rate of the US dollar against the rupiah, companies listed on the exchange will issue information to provide return compensation to compensate for foreign investors' losses due to the depreciation of the rupiah. However, this action takes time, so in general, the market will discount the stock price first so that the return will increase to equal the change in the value of the US dollar exchange rate.

Effect of Bank Indonesia Sharia Certificate Return Rates on Stock Index

Bank Indonesia Sharia Certificates (SBIS) are securities based on short-term sharia principles in rupiah currency issued by Bank Indonesia. The mechanism of SBIS issuance uses the auction system, and participants who can participate in the auction are Islamic commercial banks (UUS) using the ju'alah contract. Then the Islamic bank is entitled to get returns from SBIS. The rate of return is adjusted to the weighted average discount rate on conventional SBIs.

The contract used in the Bank Indonesia Sharia Certificates (SBIS) today is based on the ju'alah agreement. Ju'alah is a promise or commitment ( iltizam ) to provide absolute returns ( 'iwadh / ju'l ) for achieving results ( natijah) determined from a job.

Bank Indonesia Sharia Certificate (SBIS) also functions as one of the instruments to assist in sharia bank investment in the event of excess funds. In the issuance of Bank Indonesia Sharia Certificates (SBIS) the contract used is ju'alah. Then the Islamic bank that places funds in the Bank Indonesia Syariah Certificate (SBIS) is entitled to receive wages ( ujrah) for services to help maintain Indonesia's monetary balance. The level of returns provided by Bank Indonesia (BI) refers to conventional Bank Indonesia Certificates (SBI) so that it will not trigger a profit gap obtained from the placement of these funds by Islamic banks. When the returns obtained by Islamic banks in investing in Bank Indonesia Sharia Certificates (SBIS) are substantial, certainly the profits will be obtained by Islamic banks, then the return generated is divided into Third Party Funds (DPK), namely customers who save, deposits will also be high. It can attract investors to switch to invest in Islamic banks than other investment instruments, namely the Islamic capital market. When investor interest falls to invest in the Islamic capital market, of course, it will trigger a decline in the stock price index.

Previous research

Several empirical studies with various studies conducted by economists previously more or less provide an overview and can be used as a reference in this study.

Citra Puspa Mawarni \& Widiasmara (2018) used multiple linear analyses and found that Bank Indonesia's interest rates had a non-significant negative influence on ISSI with a regression coefficient of -5.303 with the level significance of t $0.055(>0.05)$ during the period of $2011-2017$. This finding is 
different from Antokolaras (2017), who found BI interest rates had a significant positive influence on ISSI with a regression coefficient of 0.020 with the empirical significance of t $0.020(<0.05)$.

Hafni (2015) used the Ordinary Least Square (OLS) model and found that in Indonesia during the period January 2010 - December 2014 inflation significantly affected ISSI with a regression coefficient of 0.161 and empirical significance of t $0.006(<0.10)$. Besides, Suciningtias \& Khoiroh $(2015)$ used multiple linear analysis models and found that in Indonesia during the period May 2011 - May 2013 inflation significantly affected ISSI with a regression coefficient of -0.302 and empirical significance of $t 0.040$ $(<0.10)$.

Putri (2018) conducted multiple linear analyses and found that the rupiah exchange rate had a significant negative effect on ISSI with a regression coefficient of -0.027 . This research is supported by Arintika \& Isynuwardhana (2015), who found that the exchange rate had a significant negative effect on ISSI in the short term. With a regression coefficient of -0.020 .

Antokolaras (2017) used multiple linear regression analysis models and concluded SBIS has a significant positive impact on ISSI with regression coefficient 0.308 that during the period 2012-2016. Ardana (2016) backed the result by conducting Error Correction Model (ECM) analysis and found that in Indonesia during the period May 2011 - September 2015 SBIS impact positively and significantly on ISSI in the short and long term..

\section{METHODOLOGY}

Econometric Model

Methodology explains what research method used, how the data collected, and proceed. This step quantitatively or qualitatively to get more explanation in the result and discussion.

As mentioned earlier, this study will observe the effect of Macroeconomic Variables on the Indonesian Sharia Stock Index (ISSI) using a multiple regression analysis tool with the Error Correction Model (ECM) approach, whose formulation estimator models are:

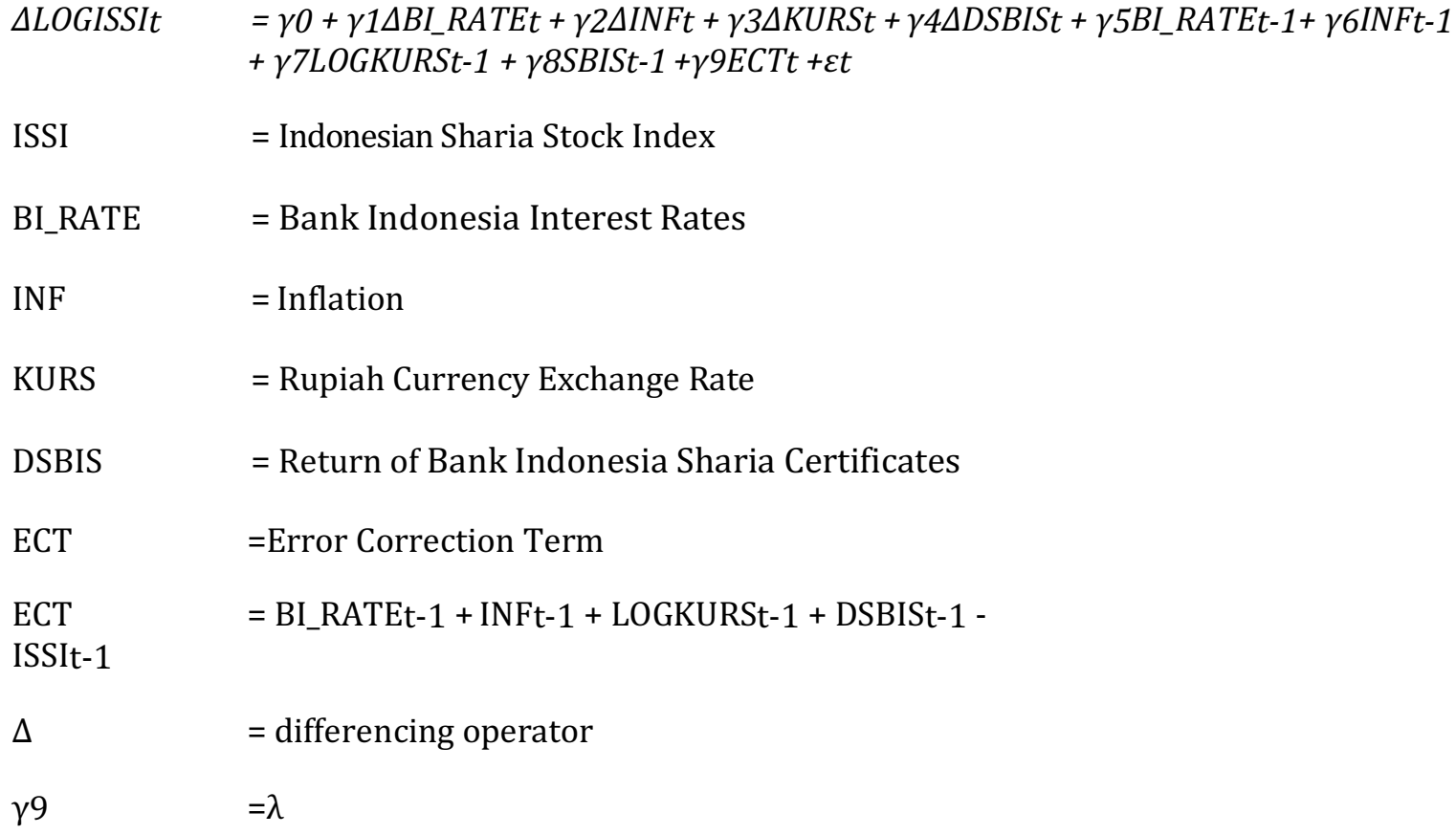




$$
\begin{array}{ll}
\gamma 0 & =\lambda \beta 0 \\
\gamma 1, \gamma 2, \gamma 3, \gamma 4 & =\text { short-term regression coefficients BI_RATE, INF, KURS dan DSBIS } \\
\gamma 5 & =-\lambda(1-\beta 1) \\
\gamma 6 & =-\lambda(1-\beta 2) \\
\gamma 7 & =-\lambda(1-\beta 3) \\
\gamma 8 & =-\lambda(1-\beta 4) \\
\beta 0 & =\text { long-term constant } \\
\beta 1, \beta 2, \beta 3, \beta 4 & =\text { long-term regression coefficients BI_RATE, INF, LOGKURS dan DSBIS } \\
\varepsilon & =\text { error term } \\
\mathrm{t} & =\text { year }
\end{array}
$$

The estimation steps will include the estimation of model parameters, the classical assumption test estimator, the model goodness test, and the effect validity test.

Type and Sources of Data

The data used in this study are secondary. The secondary data is in the form of Sharia Stock Index (ISSI) growth data obtained from the closing price at the end of each month starting from October 2013 September 2017, while macroeconomic variables are obtained each month during the period October 2013-September 2017.

The population and sample in this study is the stock index listed on the Indonesia Stock Exchange (IDX), the Indonesian Sharia Stock Index (ISSI). For ISSI data obtained from the site (https://www.duniainvest.com). For data such as interest rates obtained from the site (www.bps.go.id). For inflation data, the rupiah exchange rate and the rate of return of the Bank Indonesia Syariah Certificate (SBIS) are obtained from the official website of BI (www.bi.go.id). This research will be analyzed using the Error Correction Model (ECM).

\section{RESULT AND DISCUSSION}

Estimation Result

In this study, to observe the effect of macroeconomic variables on the Indonesian Sharia Stock Index (ISSI), this research used multiple regression analysis tools with the Error Correction Model (ECM) approach. The ECM (Error Correction Model) model is an econometric model that can be used to find short and long term balance regression equations

In this study, to observe the effect of macroeconomic variables on the Indonesian Sharia Stock Index (ISSI), this research used multiple regression analysis tools with the Error Correction Model (ECM) approach. The ECM (Error Correction Model) model is an econometric model that can be used to find short and long term balance regression equations 
Table 1. Model Econometric Result

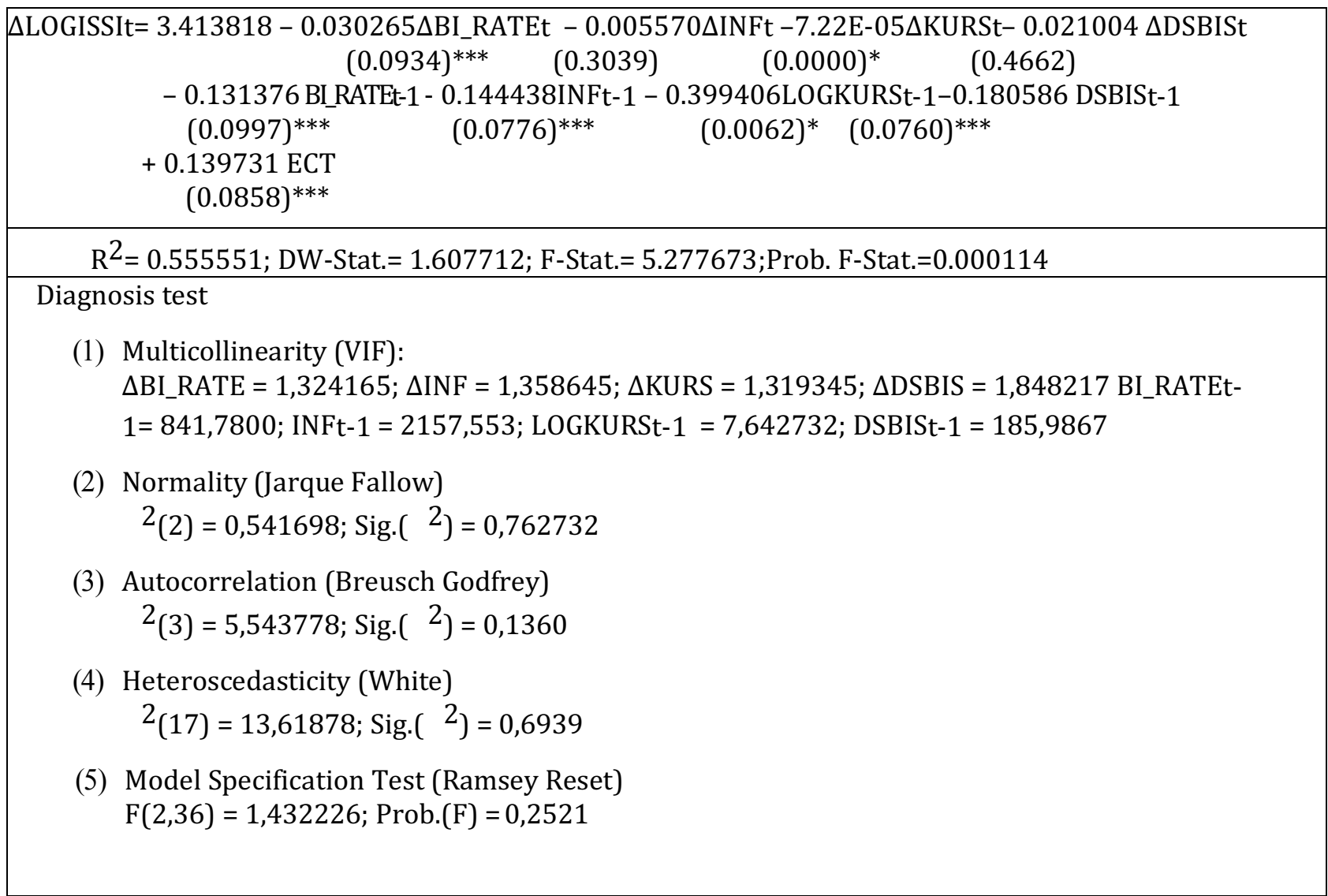

Note: ${ }^{*}$ Significant at $\alpha=0.01 ;{ }^{* *}$ Significant at $\alpha=0.05 ;{ }^{* * *}$ Significant at $\alpha=0.10$. The number in parentheses is the empirical probability ( $\mathrm{p}$ value) t-statistic.

From the results of the ECM regression analysis can be written in the form of linear equations to:

$$
\begin{array}{ll}
\text { DLOGISSI } & =3.413818-0.030265 \text { D(BI_RATE })-0.005570 \text { D(INF) }-0.00000722 \text { D(KURS) }- \\
& 0.021004 \text { D(DSBIS) }-0.131376 \text { BI_RATE }(-1)-0.144438 \text { INF(-1) }-0.399406 \\
& \text { LOG(KURS(-1) }-0.180586 \text { DSBIS }(-1)+0.139731 \text { ECT }
\end{array}
$$

The above model is a short-term model. The long-term model must see a balance which includes a series of adjustment processes that bring each shock to equilibrium. In other words in the long run it spossible to make full adjustments for any changes that arise. The results of manual calculations to obtain long-term coefficients are as follows: 
International Journal of Management, Entrepreneurship, Social Science and Humanities (IJMESH), Vol. 3 (1), 1-15 The Influence of Determining Factors on Islamic Stock Index in Indonesia Azhar Alam, Galuh Thifal Anggraeni, Muhammad Anas

Table 2. Long Term Coefisient Regresion

\begin{tabular}{ccc}
\hline Variable & Calculation & Results \\
\hline C & $3.413818 / 0.139731$ & $=24.43136$ \\
BIRATE(-1) & $(-0.131376+0.139731) /$ & $=05979$ \\
INF(-1) & 0.139731 & $=-0.03369$ \\
& $(-0.144438+0.139731) /$ & $=-1.85839$ \\
LOG(KURS(-1)) & 0.139731 & $=-0.29238$ \\
DSBIS(-1) & $(-0.399406+0.139731) /$ & \\
& 0.139731 & \\
\hline
\end{tabular}

\section{Source : Processed Data}

Based on the calculation results in table 1, the long-term model can be written in a linear equation as follows:

LOGISSI

$$
\begin{aligned}
& =24,43136+0,05979 \text { BIRATE(-1)-0,03369INF(-1)-1,85839 KURS(-1)- } \\
& \text { 0,29238DSBIS(-1) }
\end{aligned}
$$

Classic assumptions and statistical tests ae conducted to test the validity of the estimation results. The test is intended to decide whether the interpretations of the parameters are theoretically significant and statistically significant.

Validity Test Influence

The validity test is used to measure how much influence each independent variable has on the dependent variable. The hypothesis formulation is $\mathrm{H} 0: \beta \mathrm{i}=0$; I independent variable has no significant effect and HA: $\beta \mathrm{i} \neq 0$; the independent variable to I has a significant effect. Then the test criteria are His rejected if the statistical significance of $\mathrm{ti}<\alpha$ and $\mathrm{HO}$ is accepted if the statistical significance of $\mathrm{ti}>\alpha$.

Table 3 Result of T-Validity Test

\begin{tabular}{lccc}
\hline Variabel & T-Probability & Criteria & Conclusions \\
\hline D(BIRATE) & 0.0934 & $<0.10$ & Signicant Influence \\
D(INF) & 0.3039 & $>0.10$ & Not Signicant Influence \\
D(KURS) & 0.0000 & $<0.01$ & Signicant Influence \\
D(DSBIS) & 0,4662 & $>0.10$ & Not Signicant Influence \\
BIRATE (-1) & 0.0997 & $<0.10$ & Signicant Influence \\
INF(-1) & 0.0776 & $<0.10$ & Signicant Influence \\
LOG(KURS(-1)) & 0.0062 & $<0.01$ & Signicant Influence \\
DSBIS(-1) & 0.0760 & $<0.10$ & Signicant Influence \\
\hline
\end{tabular}

Source: Processed Data

Interpretation of the Effect of Independent Variables

From the effect validity test ( $t$-test) above, the BI interest rate variable and the rupiah exchange rate have a significant effect on the Indonesian Sharia Stock Index in the short term. 
While in the long nuthe variable BI interest rates, inflation, rupiah exchange rates, and the level of return of Bank Indonesia Sharia Certificates have a significanteffect.

Based on the regression results using the ECM method, the pattern of the relationship between the BI interest rate variable and the Indonesian Syariah Stock Index (ISSI) is logarithmic-linear. The regression coefficient of the Bank Indonesia interest rate variable in the short term is -0.030265 . This shows that in the short term if Bank Indonesia interest rates rise by one per cent, the Indonesian Syariah StodkIndex (ISSI) will decrease by $0.030265 \times 100=3.02$ per cent. In the long term, BI interest rates have aregression coefficient of 0.05979 . This shows that in the long run if Bank Indonesia interest rates rise byone per cent, the Indonesian Syariah Stock Index (ISSI) will rise by 0.05979 per cent.

The pattern of the relationship between the inflation variable and the Indonesian Syariah StockIndex (ISSI) is logarithmic-linear. The inflation variable has a short-term coefficient of -0.005570 . This shows in the short term if inflation rises by one per cent, then the Indonesian Syariah Stock Index (ISSI) will decrease by $0.005570 \times 100=0.55$ per cent. In the long run, inflation has a regression coefficient of -0.03369 . This shows that in the long run if inflation rises by one per cent, the Indonesian Syariah Stock Index (ISSI) will decrease by $0.03369 \times 100=3.36$ per cent.

The pattern of the relationship between the rupiah exchange rate variable and the Indonesian Sharia Stock Index (ISSI) in the short run is logarithm-linear. The rupiah exchange rate variable has a short-term regression coefficient of -0.0000722 . This shows in the short term if the rupiah exchange rate rises by one rupiah per USD, then the Indonesian Sharia Stock Index (ISSI) will decrease by $0.0000722 \times 100=0.00$ per cent. In the long term, the rupiah exchange rate has a regression coefficient of -1.885839 . The pattern of the relationship between the rupiah exchange rate variable and the Indonesian Sharia Stock Index (ISSI) in the long run is logarithms. This shows that in the long run, if the rupiah exchange rate rises by one rupiah per USD, the Indonesian Sharia Stock Index (ISSI) will decrease by 1.85839x $100=185.83$ per cent.

The pattern of the relationship between the variable rate of return of the Bank Indonesia Sharia Certificates (SBIS) and the Sharia Indonesia Stock Index (ISSI) is logarithmiclinear. The variable returnslevel of Bank Indonesia Sharia Certificates has a regression coefficient of -0.021004 . This shows in the short term if the returns rate of Bank Indonesia Sharia Certificates (SBIS) rises by one per cent then the Indonesian Sharia Stock Index (ISSI) will decrease by $0.021004 \times 100=2.10$ per cent. In the long term, the returns rate of a Bank Indonesia Sharia Certificates (SBIS) has a regression coefficient of -0.292388 . This shows in the long run that if the returns rate of Bank Indonesia Sharia Certificate (SBIS) rises by one per cent, the Indonesian Sharia Stock Index (ISSI) will decrease by $0.29238 \times 100=29.23$ per cent.

Economic Discussion On Results

\section{Bank Indonesia Interest Rates Against Indonesian Sharia Stock Index}

The results of the regression test found that the BI interest rate had a negative and significant effect on the Indonesian Sharia Stock Index (ISSI) in the short term. This shows that when the BI interest rate rises, it will reduce the Indonesian Sharia Stock Index (ISSI). This is by research conducted by Citra Puspa Mawarni \& Widiasmara (2018) who found that interest rates have a negative relationship with Islamic stock price indexes. It can be concluded that the lower 
the $\mathrm{BI}$ interest rate, the higher the $\mathrm{B}$ and deposit interest rates and loans from domestic banks, the credit burden will increase, and net income will decrease. A decrease in net profit results in a decrease in the stock price in the market. Thus encouraging investors to intend to switch to investing in banking securities that have a fixed value rather than investing in the capital market where the benefits obtained are still uncertain due to fluctuating stock prices.

Whereas in the long run, BI interest rates have a positive and significant effect on the Indonesian Sharia Stock Index (ISSI). An increase in interest rates will have an impact on increased investment andeconomic activity that will lead to an increase in the Indonesian Sharia Stock Index (ISSI).

\section{Inflation in Indonesia's Sharia Stock Index}

In the long-run inflation has a significant negative effect. This indicates that changes in inflation will give meaning to the Indonesian Sharia Stock Index (ISSI) between October 2013 and September 2017. Where when the inflation rate increases, it will reduce the Indonesian Sharia Stock Index (ISSI). The results of this study support research conducted by Aisiyah \& Khoiroh (2015), which shows that inflation has a negative and significant effect on the Indonesian Sharia Stock Index (ISSI).

Incremental inflation consequently leads to rising prices in general. This condition can increase production costs from rising raw material prices while people's purchasing power will further weaken. Weakening purchasing power causes some companies to be less able to sell company products, thereby affecting the level of sales and weakening corporate profitability. The decline in the company's profitability will also affect the company's stock price decline. The decline in the company's stock price is considered less attractive and less profitable for investors because the return to be distributed by the company to shareholders will also decrease. This makes consideration for investors who prefer to refrain from investing in companies listed on the Islamic capital market so that it affects the demand for Islamic shares and when the offer of Islamic shares is higher than the demand, it will reduce the Indonesian Syariah Stock Index ( ISSI).

\section{Rupiah Exchange Rate against Indonesian Sharia Stock Index}

Variable of rupiah currency exchange rates toward dollar in the short and long term has a negative influence significantly to the ISSI. This is consistent with research by Putri (2018). Depreciation of the rupiah against the dollar means that the value of the rupiah weakens so that the exchange of the dollar will get a higher rupiah value. The weakening of the rupiah will affect companies differently in the category of import or export.

For importer companies, of course, the depreciation of the rupiah will hurt the company because it will bear higher costs. The same thing is experienced by companies that have debt in the form of dollars, of course, the depreciation of the rupiah will be detrimental because the company will pay more significant obligations, of course, this will reduce the company's profitability. When the profitability of the company goes down, many investors choose to sell their shares and choose to switch to other investments such as the foreign exchange market. The attitude of these investors can reduce the price of company shares and affect the demand for 
shares on the Indonesia Stock Exchange (IDX) including sharia shares on the Indonesian Sharia Stock Index (ISSI) so that it results in a declining stock index movement.

\section{The Level of Returns of Bank Indonesia Sharia Certificates to the Indonesian Sharia Stock Index}

In the long period term, Bank Indonesia Sharia Certificates have influential negative and significant to the Indonesian Sharia Stock Index (ISSI). This finding supports Prabowo (2013) study, which shows that the SBIS variable has a causality relationship on the Indonesian Syariah Stock Index (ISSI). This can be reflected in the economy that the ISSI and SBIS equally the Islamic investment instruments, they synergize to increase investment in Indonesia, particularly in the Islamic capital market.

\section{CONCLUSION}

Based on the results of a regression analysis using Error Correction Model (ECM) and the effect validity t-test on the significance $(\alpha)$ of 0.10 , the $\mathrm{BI}$ interest rates, inflation, the rupiah currency exchange rate and the rate of return of Bank Indonesia Sharia Certificates have a significant negative effect on the Indonesian Sharia Stock Index (ISSI) in long term estimation. However, in the short term, both inflation and the rate of Bank Indonesia Sharia Certificates return have no significant negative effect. In contrast, $\mathrm{BI}$ interest rates and rupiah currency exchange rates have a significant negative effect on ISSI.

This study suggests the importance of attention to macroeconomic variables impacts such as $\mathrm{BI}$ interest rate inflation, the rupiah currency exchange rate, and the rate of return of Bank Indonesia Sharia Certificates which hurt ISSI. This information would be useful for a regular investor of ISSI and the government to make a policy that supports the development of ISSI. This paper also recommended the Indonesian Central Bank to effectively manage their monetary policy and promote ISSI as an alternative investment which is resistant by the negative effect of inflation in short term analysis.

\section{REFERENCES}

Aisiyah, S., \& Khoiroh, R. (2015). Analisis Dampak Variabel Makroekonomi terhadap Indeks Saham Syariah Indonesia[Analysis of the Impact of Macroeconomic Variables on the Indonesian Sharia Stock Index]. Jurnal Ekonomi, 2(1).

Antokolaras, A. (2017). Analisis Pengaruh Variabel Makroekonomi Domestik dan Makroekonomi Global terhadap Indeks Saham Syariah Indonesia Periode 2012-2016[Analysis of the Influence of Domestic Macroeconomic and Global Macroeconomic Variables on the Indonesian Sharia Stock Index]. UIN Syarif Hidayatullah Jakarta.

Ardana, Y. (2016). Variabel Makroekonomi Terhadap Indeks Saham Syariah ( Periode Mei 2011September 2015 Dengan Model ECM )[Macroeconomic Variables Against Sharia Stock Index (Period of May 2011-September 2015 with ECM Model)]. Media Trend, 11(2), 117-130. https://doi.org/10.21107/mediatrend.v11i2.1441

Arintika, R. Y., \& Isynuwardhana. (2015). Pengaruh Inflasi, Suku Bunga SBI, KURS Valuta Asing, Indeks Harga Konsumen dan Harga Emas terhadap Indeks Saham Syariah Indonesia [Influence of Inflation, SBI Interest Rates, Foreign Exchange, Consumer Price Index and Gold Price on ISSI]. In eProceeding of Management. 
Bahloul, S., Mroua, M., \& Naifar, N. (2017). The impact of macroeconomic and conventional stock market variables on Islamic index returns under regime-switching. Borsa Istanbul Review, 17(1), 62-74. https://doi.org/10.1016/j.bir.2016.09.003

Brigham, E. F., \& Houston, J. F. (2013). Dasar-Dasar Manajemen Keuangan [Fundamentals of Financial Management] (11th ed.). Jakarta: Salemba Empat.

Darmaji, T., \& Hendi, F. M. (2006). Pasar Modal di Indonesia: Pendekatan Tanya Jawab [Capital Markets in Indonesia: A Question and Answer Approach]. Jakarta: Salemba Empat.

Fabozzi, F. J. (2000). Manajemen Investasi [Investment Management]. Jakarta: Pearson Education Asia Pte Ltd. Prentice-Hall: Salemba Empat.

Hafni, H. (2015). Dampak Fluktuasi Inflasi, Sertifikat Bank Indonesia Syariah, Exchange Rate dan Harga Emas Dunia Terhadap Jakarta Islamic Index Periode (Jan 2010 - Des 2014). UIN Syarif Hidayatullah Jakarta.

Halim, A. (2005). Analisis Investasi Edisi Kedua[Investment Analysis Second Edition]. Jakarta: Salemba Empat.

Iskandar, A. Z. (2003). Pasar Modal: Teori dan Aplikasi [Capital Markets: Theory and Application]. Jakarta: Yayasan Pancur Siwah.

Karya, D., \& Syamsudin, S. (2016). Makroekonomi: Pengnatar untuk Manajemen [Macroeconomics: Introduction to Management] (1st ed.). Jakarta: Rajawali Pers.

Kewal, S. S. (2012). Pengaruh Inflasi, Suku Bunga, Kurs dan Pertumbuhan PDB terhadap Indeks Harga Saham Gabungan [Effects of Inflation, Interest Rates, Exchange Rates and GDP Growth on the Composite Stock Price Index]. Jurnal Ekonomi, 8(1).

Manurung, J. J., \& Manurung, A. H. (2009). Ekonomi Keuangan dan Kebijakan Moneter Cetakan Pertama [Financial Economics and Monetary Policy First Edition]. Jakarta: Salemba Empat.

Maulita, D., \& Arifin, M. (2018). Pengaruh Return On Investment (Roi) Dan Earning Per Share (Eps) Terhadap Return Saham Syariah [The Influence of Return On Investment (Roi) and Earning Per Share (EPS) on Sharia Stock Returns]. Jurnal Manajemen, 8(1), 10-19.

Mawarni, C. P., \& Widiasmara, A. (2018). Pengaruh Fed Rate , Harga Minyak Dunia , Bi Rate , Inflasi Dan Kurs Rupiah Terhadap Indeks Saham Syariah Indonesia (ISSI) Periode Tahun 2011-2017 [Effects of Fed Rate, World Oil Prices, Bi Rate, Inflation and Rupiah Exchange Rate on ISSI]. INVENTORY, 2(2), 281297.

Natarsyah, S. (2000). Analisis Pengaruh Beberapa Faktor Fundamental dan Risiko Sistematik terhadap Harga Saham: Kasus Industri Barang Konsumsi yang Go-Public di Pasar Modal Indonesia[Analysis of the Effects of Some Fundamental Factors and Systematic Risk on Stock Prices]. Jurnal Ekonomi Dan Bisnis Indonesia, 15(3), 294-312.

Otoritas Jasa Keuangan. (2017). Survey Nasional Literasi dan Inklusi Keuangan 2016 [National Literacy and Financial Inclusion Survey 2016]. Retrieved October 22, 2019, from http://www.ojk.go.id/id/berita-dan-kegiatan/siaran- pers/Documents/Pages/Siaran-Pers-OJK-IndeksLiterasi-dan- Inklusi-Keuangan-Meningkat/17.01.23 Tayangan Presscon nett.compressed.pdf

Prabowo, D. (2013). Analisis Pengaruh Inflasi, Sertifikat Bank Indonesia Syariah dan Jumlah Uang Beredar terhadap Indeks Syariah yang terdaftar di Indeks Saham Syariah Indonesia Periode Mei 2010 April 2013. UIN Syarif Hidayatullah Jakarta.

Putri, O. L. (2018). Analisa Pengaruh Faktor Makro Ekonomi Terhadap Indeks Saham Syariah Indonesia (Studi Empiris Saham Syariah di BEI Periode 30 Juni 2011 - 31 Juli 2016)[Analysis of the Effect of Macroeconomic Factors on the Indonesian Sharia Stock Index ]. Universitas Islam Indonesia. 
Rachmawati, M., \& Laila, N. (2015). Faktor Makroekonomi Yang Mempengaruhi Pergerakan Harga Saham Pada Indeks Saham Syariah Indonesia (Issi) Di Bursa Efek Indonesia (Bei)[Macroeconomic Factors That Affect Share Price Movements on the Indonesian Sharia Stock Index (ISSI)]. JESTT, 2(11), 928-942.

Samsul, M. (2006). Pasar Modal dan Manajemen Portofolio [Capital Markets and Portfolio Management]. Surabaya: Erlangga.

Setiawan, C., \& Kanila Wati, N. P. (2019). Factors Affecting the Performance of Sharia Equity Funds in Indonesia. Iranian Journal of Management Studies, 0(4), 481-507. https://doi.org/10.22059/ijms.2019.263411.673253

Suciningtias, S. A., \& Khoiroh, R. (2015). Analisis Dampak Variabel Makroekonomi terhadap Indeks Saham Syariah Indonesia. Jurnal Ekonomi, 2(1).

Aisiyah, S., \& Khoiroh, R. (2015). Analisis Dampak Variabel Makroekonomi terhadap Indeks Saham Syariah Indonesia[Analysis of the Impact of Macroeconomic Variables on the Indonesian Sharia Stock Index]. Jurnal Ekonomi, 2(1).

Antokolaras, A. (2017). Analisis Pengaruh Variabel Makroekonomi Domestik dan Makroekonomi Global terhadap Indeks Saham Syariah Indonesia Periode 2012-2016[Analysis of the Influence of Domestic Macroeconomic and Global Macroeconomic Variables on the Indonesian Sharia Stock Index]. UIN Syarif Hidayatullah Jakarta.

Ardana, Y. (2016). Variabel Makroekonomi Terhadap Indeks Saham Syariah ( Periode Mei 2011September 2015 Dengan Model ECM )[Macroeconomic Variables Against Sharia Stock Index (Period of May 2011-September 2015 with ECM Model)]. Media Trend, 11(2), 117-130. https://doi.org/10.21107/mediatrend.v11i2.1441

Arintika, R. Y., \& Isynuwardhana. (2015). Pengaruh Inflasi, Suku Bunga SBI, KURS Valuta Asing, Indeks Harga Konsumen dan Harga Emas terhadap Indeks Saham Syariah Indonesia [Influence of Inflation, SBI Interest Rates, Foreign Exchange, Consumer Price Index and Gold Price on ISSI]. In eProceeding of Management.

Bahloul, S., Mroua, M., \& Naifar, N. (2017). The impact of macroeconomic and conventional stock market variables on Islamic index returns under regime-switching. Borsa Istanbul Review, 17(1), 62-74. https://doi.org/10.1016/j.bir.2016.09.003

Brigham, E. F., \& Houston, J. F. (2013). Dasar-Dasar Manajemen Keuangan [Fundamentals of Financial Management] (11th ed.). Jakarta: Salemba Empat.

Darmaji, T., \& Hendi, F. M. (2006). Pasar Modal di Indonesia: Pendekatan Tanya Jawab [Capital Markets in Indonesia: A Question and Answer Approach]. Jakarta: Salemba Empat.

Fabozzi, F. J. (2000). Manajemen Investasi [Investment Management]. Jakarta: Pearson Education Asia Pte Ltd. Prentice-Hall: Salemba Empat.

Halim, A. (2005). Analisis Investasi Edisi Kedua[Investment Analysis Second Edition]. Jakarta: Salemba Empat.

Iskandar, A. Z. (2003). Pasar Modal: Teori dan Aplikasi [Capital Markets: Theory and Application]. Jakarta: Yayasan Pancur Siwah.

Karya, D., \& Syamsudin, S. (2016). Makroekonomi: Pengnatar untuk Manajemen [Macroeconomics: Introduction to Management] (1st ed.). Jakarta: Rajawali Pers.

Kewal, S. S. (2012). Pengaruh Inflasi, Suku Bunga, Kurs dan Pertumbuhan PDB terhadap Indeks Harga Saham Gabungan [Effects of Inflation, Interest Rates, Exchange Rates and GDP Growth on the Composite Stock Price Index]. Jurnal Ekonomi, 8(1). 
Manurung, J. J., \& Manurung, A. H. (2009). Ekonomi Keuangan dan Kebijakan Moneter Cetakan Pertama [Financial Economics and Monetary Policy First Edition]. Jakarta: Salemba Empat.

Maulita, D., \& Arifin, M. (2018). Pengaruh Return On Investment (Roi) Dan Earning Per Share (Eps) Terhadap Return Saham Syariah [The Influence of Return On Investment (Roi) and Earning Per Share (EPS) on Sharia Stock Returns]. Jurnal Manajemen, 8(1), 10-19.

Mawarni, C. P., \& Widiasmara, A. (2018). Pengaruh Fed Rate , Harga Minyak Dunia , Bi Rate , Inflasi Dan Kurs Rupiah Terhadap Indeks Saham Syariah Indonesia (ISSI) Periode Tahun 2011-2017 [Effects of Fed Rate, World Oil Prices, Bi Rate, Inflation and Rupiah Exchange Rate on ISSI]. INVENTORY, 2(2), 281297.

Natarsyah, S. (2000). Analisis Pengaruh Beberapa Faktor Fundamental dan Risiko Sistematik terhadap Harga Saham: Kasus Industri Barang Konsumsi yang Go-Public di Pasar Modal Indonesia[Analysis of the Effects of Some Fundamental Factors and Systematic Risk on Stock Prices]. Jurnal Ekonomi Dan Bisnis Indonesia, 15(3), 294-312.

Otoritas Jasa Keuangan. (2017). Survey Nasional Literasi dan Inklusi Keuangan 2016 [National Literacy and Financial Inclusion Survey 2016]. Retrieved October 22, 2019, from http://www.ojk.go.id/id/berita-dan-kegiatan/siaran- pers/Documents/Pages/Siaran-Pers-OJK-IndeksLiterasi-dan- Inklusi-Keuangan-Meningkat/17.01.23 Tayangan Presscon nett.compressed.pdf

Prabowo, D. (2013). Analisis Pengaruh Inflasi, Sertifikat Bank Indonesia Syariah dan Jumlah Uang Beredar terhadap Indeks Syariah yang terdaftar di Indeks Saham Syariah Indonesia Periode Mei 2010 April 2013. UIN Syarif Hidayatullah Jakarta.

Putri, O. L. (2018). Analisa Pengaruh Faktor Makro Ekonomi Terhadap Indeks Saham Syariah Indonesia (Studi Empiris Saham Syariah di BEI Periode 30 Juni 2011 - 31 Juli 2016)[Analysis of the Effect of Macroeconomic Factors on the Indonesian Sharia Stock Index ]. Universitas Islam Indonesia.

Rachmawati, M., \& Laila, N. (2015). Faktor Makroekonomi Yang Mempengaruhi Pergerakan Harga Saham Pada Indeks Saham Syariah Indonesia (Issi) Di Bursa Efek Indonesia (Bei)[Macroeconomic Factors That Affect Share Price Movements on the Indonesian Sharia Stock Index (ISSI)]. JESTT, 2(11), 928-942.

Samsul, M. (2006). Pasar Modal dan Manajemen Portofolio [Capital Markets and Portfolio Management]. Surabaya: Erlangga.

Setiawan, C., \& Kanila Wati, N. P. (2019). Factors Affecting the Performance of Sharia Equity Funds in Indonesia. Iranian Journal of Management Studies, 0(4), 481-507. https://doi.org/10.22059/ijms.2019.263411.673253

Sukirno, S. (2013). Makroekonomi: Teori Pengantar[Macroeconomics: Introduction Theory]. Jakarta: PT. Raja Grafindo Persada.

Sukirno, S. (2014). Ekonomi Pembangunan: Proses, Masalah dan Dasar Kebijakan Edisi Kedua[Development Economics: Process, Issues and Policy Basis Second Edition]. Jakarta: Kencana Prenadamedia Group.

Tandelilin, E. (2010). Potofolio dan Investasi: Teori dan Aplikasi [Portfolios and Investments: Theory and Application] (1th ed.). Yogyakarta: Kanisius.

Taslim, A., \& Wijayanto, A. (2016). Pengaruh Frekuensi Perdagangan Saham,Volume Perdagangan Saham,Kapitalisasi Pasar Dan Jumlah Hari Perdagangan Terhadap Return Saham[Effect of Stock Trading Frequency, Stock Trading Volume, Market Capitalization and Number of Trading Days on Stock Return]. Management Analysis Jounal, 5(1), 1-6. 